\title{
Paraaortic Lymph Node
}

National Cancer Institute

\section{Source}

National Cancer Institute. Paraaortic Lymph Node. NCI Thesaurus. Code C77643.

A lymph node located adjacent to the lumbar region of the spine. 